\title{
Colin Titmus
}

To besedilo skuša biti pregled ponudbe za izobraževanje odraslih; bralca bo seznanilo z načini, s katerimi lahko pritegnemo odraslega, da se vključi v izobraževanje. To lahko dosežemo tako, da spremenimo ponudbo ali da spremenimo odraslega ali da spremenimo svet, v katerem obstaja določena ponudba in v katerem odrasla oseba živi.

Omenjena, na videz preprosta naloga, je problem, ki so ga izobraževalci že od začetkov izobraževanja odraslih skušali razrešiti teoretično in včasih tudi v praksi, vendar jim je to le delno uspelo.

Ugotavljamo celo, da si ne glede na uspešnost njihovih prizadevanj težko ustvarimo primerno predstavo o tej nalogi, precej težje, kot menijo številni pisci. Dejansko ni jasne ločnice med nagnjenostjo k izobraževanju in med odporom do njega, temveč gre za nepretrgano vrsto stališč, ki segajo od velikega navdušenja odraslega, da bi se lotil izobraževanja, prek neodločnosti, mlačnosti, pa vse do sovraštva do te dejavnosti. Prav tako ni določeno, kaj vse zajema omenjeni čustveni odnos posameznika. Ali pri določeni osebi ta odnos meri na vsa področja sistematičnega učenja oz. študija ali le na nekatere vrste učenja? Kaj je tisto, kar človeka privlači ali odbija - vsebina in vrsta izobraževanja ali nemara njegov rezultat? Ali odnos osebe izhaja iz nekih njenih izkušenj, ki morda sploh nimajo razvidne zveze z izobraževanjem? Mar ljudje res čutijo odpor v smislu brezbrižnosti ali odtujenosti ali pa jih izobraževanje pravzaprav privlači, vendar si zanj ne utrgajo časa, saj za njihov cas »tekmujejo« se druge dejavnosti, ki se zde prijetneǰ̌e in koristnejše? Ali je njihov odnos do izobraževanja močno ustaljen ali pa bi se utegnil spremeniti - in če, kateri dejavniki bi verjetno povzročili spremembo?

Ker se odgovori na ta vprašanja razlikujejo glede na osebo, o kateri se pogovarjamo, skoraj gotovo ne obstaja en sam tip odraslega, ki čuti odpor do izobraževanja in torej tudi ne nek enoten način za pritegnitev odraslih oseb k izobraževanju. Pravzaprav se zdi obravnava tako številnih in različnih primerov zastrašujoča in morda celo nerealna naloga. $V$ njen prid pa vendar govorijo najrazličnejše možnosti v zvezi z vsebino, načini in dosežki izobraževanja odraslih. Na voljo je toliko možnosti, da se človek sprašuje, ali je treba iskati nove vrste ponudbe ali pa gre nemara bolj za to, da skušamo kombinirati obstoječe možnosti s potrebami določenega posameznika. Če se taka kombinacija izkaže za neuspešno, vzrok za nezainteresiranost odraslega verjetno ni v izobraževalni ponudbi, ne glede na to, kako jo definiramo, temveč drugje.

\section{Nadaljevanje začetnega izobraževanja}

Danes se kot v prejšnjih stoletjih velik del rednega izobraževanja, ki se začne v otroštvu, nadaljuje v odraslem življenju. $V$ večini držav osebe, ki imajo to srečo, da so vključene v višje izobraževanje, študij končajo sele pri petindvajsetih ali celo malo kasneje. V Zvezni republiki Nemčiji na primer, kjer se novinci vpišejo na univerzo po srednji šoli z devetnajstimi leti, kjer pa gredo vendar številni mladi najprej na služenje vojaškega roka ali preživijo določen čas zunaj izobraževalne sfere, dokler jim ni na voljo mesto in zaželjena smer študija, traja povprečni čas dodiplomskega študija šest let in pol (Teichler in Sanyal, 1982). V razvitih državah je minimalna starost, pri kateri mladostniki končajo obvezno izobraževanje, večinoma 16 let, večina mladih (na primer $\vee$ ZDA) pa vztraja vsaj do osemnajstega leta. Po tem se mnogi vpišejo v splošno izobraževanje na višješolski ravni, na primer na kolidž ali ljudsko visoko šolo, ali v začetno pripravljalno smer izobraževanja za določen poklic, ki terja več let študija po srednji šoli.

Vseeno pa je izobraževanje tudi danes dejavnost, ki jo celo izobraževalci večinoma povezujejo $z$ otroško dobo. Kljub veliki razširjenosti namenskega strukturiranega in organiziranega učenja, ki se ga ljudje po svetu lotevajo po koncu otroškega oz. mladostniškega obdobja, pri izobraževanju navadno mislimo na začetno izobraževanje. Torej ni nič čudnega, da izobraževanje po otroštvu dojemamo in izvajamo v odnosu do izobraževanja $v$ otroštvu in da taka percepcija močno določa izobraževanje po otroški dobi. Tako ne le govorimo, ampak tudi razmišljamo o procesih in organizaciji sistematičnega učenja za osebe, ki so že zunaj šolske starosti, v terminih »izobraževanje po začetnem izobraževanju, po srednjem izobraževanju (višje- in visokošolsko izobraževanje), terciarno in nadaljnje izobraževanje«. Vsi izrazi izražajo položaj, ki ga dojemamo v razmerju do izobraževanja v otroštvu.

$V$ razvitih državah se je nemogoče izogniti takemu dojemanju. Šolski sistem obstaja v skladu z zakoni, ki ga določajo. Vsaka kasnejša izobraževalna ponudba izpeljuje temeljne domneve o svojih odjemalcih iz dojemanja o tem, kako se je pri njih obnesel izobraževalni sistem. Izobraževanje po začetnem izobraževanju lahko razumemo kot nadaljevanje različnih stopenj šolanja ali nasprotno kot potrebo, ki so jo v večji ali manjši meri ustvarile pomanjkljivosti solanja otrok. Primer izobraževanja, ki je nastalo kot reakcija na neustrezno začetno izobraževanje, je »education populaire« v Franciji po 2. svetovni vojni. Ta vrsta izobraževanja se je razvila $\vee$ gibanje, katerega privrženci so v načelu želeli privzeti značilnosti, ki bi bile nasprotne značilnostim francoskih šol (kot so jih dojemali). Nove lastnosti izobraževanja naj bi bile območni nadzor uporabnikov, demokratična organizacija, neformalnost, učenje, ki je osredinjeno na učenca, poudarek na procesih učenja, zlasti na aktivnih (Titmus, 1967). Zanimivo je, da je bilo nadaljnje izobraževanje (oblikovano kot reakcija na stanje v šolah) podobno izobraževanju, ki bi skušalo nadaljevati delo šol. 


\section{Kompenzucijsko izobraževanje}

Le redke države tretjega sveta lahko ponudijo otrokom devet ali enajst let rednega izobraževanja, ki je pravilo v ekonomsko razvitih družbah. Kljub temu si prizadevajo za to. $\mathrm{V}$ okoljih, kjer tega cilja še niso uresničili, večinoma gledajo na izobraževanje po otroški dobi kot na kompenzacijo za pomanjkanje prvotnega rednega šolanja. Njegov namen je zlasti boj proti nepismenosti in razvijanje osnovnih spretnosti za żivljenje. V družbah, kjer imajo tako imenovano podaljšano šolanje za vse, obstaja podobna ponudba osnovnega izobraževanja za odrasle, ki so v otroštvu izpadli iz izobraževalnega »gnezda«. V razvitih družbah se je s podaljšanjem začetnega izobraževanja povečala tudi kompenzacijska vloga izobraževanja po otroški dobi. V eni ali drugi obliki so tako zajete vse ravni začetnega izobraževanja, čeprav vanje niso vključeni prav vsi ljudje. Številne države odraslim ponujajo možnosti za dokončanje srednjega izobraževanja; ena izmed njih je Švedska (Titmus, 1981:76 ff). V višješolskem in visokošolskem izobraževanju v Evropi se povečuje tudi število mest za odrasle, ki nimajo formalnih kvalifikacij za vpis (ena od znanih tovrstnih ustanov je britanska Open University). Ta pojav delno sproža želja, da bi osebam, ki se iz kakršnih koli razlogov niso vključile $v$ višje in visokošolsko izobraževanje takoj po srednji šoli, ponudili še eno ali kompenzacijsko priložnost (Titmus, 1985:90 ff).

\section{Dopolmilno izobraževanje}

Poleg tega, da izobraževanje po otroški dobi razumemo kot kompenzacijo, velja v marsičem tudi kot dopolnilno začetnemu izobraževanju. Danes se zavedamo, da je izobraževanje po otroški dobi potrebno, saj je mogoče stlačiti vse znanje, ki ga bo oseba v življenju potrebovala, v redno začetno izobraževanje, ne glede na njegovo dolžino. Dejansko obstajajo tehtni razlogi proti raztegovanju začetnega izobraževanja $\mathrm{v}$ čas po 18. ali 19. letu starosti, pri kateri se v razvitih deželah navadno konča začetno izobraževanje.

Poglavitni razlog je ekonomska upravičenost izobraževanja. Večina razvitih držav kritično pregleduje izdatke, namenjene terciarnemu izobraževanju. Med đrugim se sprašujejo, do katere stopnje si lahko še privoščijo širjenje v višješolskega in visokošolskega izobraževanja, to je rednega dodiplomskega študija, v katerega se novinci vpišejo takoj po srednji šoli. V nekaterih okoljih preučujejo tudi morebitne izobraževalne in ekonomske prednosti, ki bi jih imel položaj, ko bi mladi ljudje, namesto da so vključeni v redni študij nekje do 25 . leta, raje pri osemnajstih ali devetnajstih zapustili šolo, se zaposlili ali si nabirali izkušnje $z$ drugimi dejavnostmi in se kasneje vrnili $\mathrm{v}$ šole oziroma se vključili v višjo ali kako drugo obliko terciarnega izobraževanja, lahko tudi ob delu.

Izobraževalne možnosti v odrasli dobi morajo obstajati. Čeprav bi imeli v otroštvu in mladosti dovolj časa za nabiranje vsega znanja, ki ga bomo potrebovali v življenju, je pač mogoče predvideti, kakšne bodo kasnejše potrebe po znanju. V preteklosti se je bilo moč zanašati na svoje osnovno oziroma splošno izobrazbo in na začetno poklicno usposobljenost, na to, da bomo vse življenje ostali v istem poklicu, isti družbi in istem kraju, da se družbene vloge ne bodo spreminjale in bodo večinoma podobne vlogam, ki so jih imeli že predniki. Življenje nekaterih vaških prebivalcev v deželah tretjega sveta bo morda še tako in ti ljudje bodo morali shajati brez vsakega for- malnega izobraževanja. Zelo malo pa je verjetno, da bi tako živel še kdo drug. Večina poznavalcev danes zastopa mnenje, da se bo v življenju vsakega človeka pojavila potreba po osvežitvi in prilagoditvi znanja, ki si ga je pridobil v mladosti, po dvigu tega znanja na višjo raven ali pa si bo človek moral pridobiti čisto nova znanja. To je ena od domnev, na katerih temelji izobraževalna ponudba po otroški dobi.

\section{Vnovitho izobraževanje in preusposabliamie}

Tudi v počasi spreminjajočih se družbah prejšnjih stoletij so se zaradi namernih in nenamernih sprememb položaja človeka lahko pojavile potrebe po novem znanju, ceprav so bile možnosti za sistematični študij majhne. Tudi če bi si danes lahko predstavljali družbe kot nespreminjajoče se na druge načine, pa bi morali upoštevati spremembe, ki jih prinaša zavest ljudi o različnih vlogah, ki jih bodo morda morali prevzemati, o številnih odločitvah za vloge in o pomembnosti sistematičnega izobraževanja pri pripravi ljudi na njihove vloge. Rast zavesti sta sprožila demokratizacija in širjenje izobraževanja sploh. Ljudje se čutijo upravičene, da spremenijo svoj način življenja. K spremembi dela jih ne silijo le zunanje okoliščine. Danes ni nič nenavadnega, če se celo osebe, ki so vrsto let posvetile doseganju strokovnosti v enem poklicu, odločijo za prehod v drug poklic, ki bo morda zahteval enak študijski trud kot prvi. Tako vedenje velja za upravičeno in ustvarjajo se priložnosti, ki ga omogočajo. Nedavno je omenjeni pojav izrabila tudi britanska vlada v svojem prizadevanju, da bi v šlah pokrila pomanjkanje učiteljev naravoslovnih ved in matematike. Iz trgovinskih in industrijskih podjetij je skušala pritegniti v poučevanje moške in ženske $z$ ustreznimi kvalifikacijami.

\section{Zustarelost Zmanja}

Povečano zavest in večja pričakovanja posameznikov so spodbudili, če že ne ustvarili zunanji pritiski. Svet, v katerem in za katerega je bila večina ljudi deležna začetnega izobraževanja, ni enak svetu, v katerem živijo kot odrasli in tako bo verjetno še veliko rodov. Velik del izobraževanja po otroški dobi je zaželen zaradi zunanjih dejavnikov, zaradi hitrih sprememb $v$ vedah in znanostih ter $v$ družbi. Zaradi sprememb postaja precejšen del začetnega izobraževanja in usposabljanja zastarel.

Za opravljanje poklicev je potrebno vedno bolj specializirano znanje. Nekvalificirani delavci vedno težje najdejo delo. Tudi kvalificirani delavci, ki vztrajajo v svojem poklicu vse življenje, morajo prilagoditi svoje spretnosti ali si pridobiti nove - in to več kot enkrat v času službovanja. Nekateri poklici izginjajo; pred petdesetimi leti so $v$ ladjedelništvu, na primer, varilci nadomestili zakovičarje. Ob razvoju računalniškega oblikovanja v prihodnosti verjetno ne bo več potrebe po klasičnih risarjih. Potreba po spremembi znanj in spretnosti se lahko pojavi zelo nenadno. Tako so na primer $v$ britanski podružnici tovarne Ford morali ključavničarske vajence sredi njihove vajeniške dobe preusmeriti v usposabljanje za monterje in vzdrževalce orodij (Shepherd, 1985).

Ne le posamezni poklici in obrti, tudi cele industrijske panoge so postale zastarele ali pa se je potreba po njih močno zmanjšala. Ponekod so tudi prenesli proizvodnjo iz tradicionalnih središč v nova, pogosto tudi v druge države. Pojavile so se nove industrijske panoge, ki uporabljajo nove tehnologije 
in zahtevajo novo znanje in kvalifikacije. Z avtomatizacijo se je v najbolj produktivnih industrijskih vejah zmanjšala potreba po delavcih. Ker je za delo potrebnih manj ljudi, zaposleni izgubljajo svoje službe. V razvitih državah že več let spremljamo prenos težišča od proizvodnih panog $k$ ponudbi storitev, $v$ tretjem svetu pa vzporedno poteka prehod od primarne proizvodnje surovin $\mathrm{k}$ izdelavi končnih izdelkov. Očitno je torej, da zaradi številnih različnih razlogov ljudje lahko pričakujemo, da se bomo v času svojega službovanja morali vključiti v katero od oblik poklicnega usposabljanja.

\section{Izobraževanje za družbene spremembe}

Učinki pospešenega razvoja znanja niso omejeni le na delovno življenje. Na področjih, kjer se spreminja cela ekonomska baza, in ta so številna, se ljudje niso prisiljeni le seliti ali se učiti novih spretnosti, temveč morajo pogosto celo občutno prilagoditi svoje osebno, družinsko in družbeno življenje. Izobraževanje za odrasle so $v$ prvih dneh industrijske revolucije uporabljali kot pomagalo za preusmerjanje kmečkega prebivalstva in domačih obrtnikov iz vasi v mesta, kjer so postali tovarniški delavci. Izobraževanje odraslih so tudi v preteklih desetletjih uporabliali za krepitev akulturacije, na primer pri zapiranju lorenskih rudnikov in železarn (Lesne, Collon in Oeconomo, 1970).

Veliko odraslih se mora vključiti v poklicno usposabljanje, da bi dobili želeno delovno mesto ali sploh obdržali svojo službo, vendar se večina zaposlenih vključi v poklicno usposabljanje, ker pričakujejo, da bodo s tem nekako izboljšali svoje življenje. Tako se nadaljuje proces, ki je za večino zaposlenih $v$ razvitem svetu realnost že od 2. svetovne vojne. Ljudje od poklicnega usposabljanja pričakujejo, da jim bo pomagalo $\mathrm{k}$ večjemu zadovoljstvu pri delu, $\mathrm{k}$ izboljšanju standarda in $\mathrm{k}$ boljšemu življenju zunaj delovnega mesta. Delovni čas je danes krajši, saj je 44-urni delovni teden, za katerega so se v zahodni Evropi tako bojevali v tridesetih letih, danes skrajšan na 35 ur. Plačani dopusti so daljši, aktivna delovna doba pa krajša, saj se zaposleni prostovoljno ali neprostovoljno upokojijo prej. Ker je treba manj časa prebiti pri opravljanju plačanega dela, ljudem ostaja več prostega časa, ki postaja tudi vedno pomembnejši. Vedno več ljudi meni, da je namen dela pravzaprav to, da človeku omogoči, da do popolnosti uživa v času zunaj dela (Goldthorpe et al., 1986-89). Skratka, podaljšan prosti čas, večja blaginja, tehnični napredek na področjih, kot sta komunikacije in potovanja, ter povprečno viša raven začetnega izobraževanja so močno vplivali na povečanje možnosti za izrabo prostega časa, ki se jih posamezniki tudi vse bolj zavedajo, povečala pa se je tudi verjetnost, da bodo ljudje te možnosti dejansko lahko do kraja izrabili, če bodo želeli.

\section{lzobraževanje za uresničevanje sumega sebe}

Andragogi obžalujejo, da ljudje premalo izrabljajo priložnosti za bogatitev samih sebe $z$ namenskim učenjem. Vseeno pa se vedno več odraslih loteva sistematičnega študija in zdi se, da za to nimajo kakega drugega razloga kot lastno zadovoljstvo, ki ga dajejo rezultati učenja ali bogato doživljanje, ki ga človek občuti ob pridobljenem znanju in spretnostih, ali zadovoljstvo ob samem učenju. Ljudje se naučijo slikati, igrati kak inštrument, pisati zgodbe in pesmi, plesati, izdelovati ko- ristne ali okrasne predmete, jadrati, ribariti, naucijo se iger, kot sta bridge ali šah, razvijajo svoje telo. Študirajo zgodovino, arheologijo, filozofijo, botaniko, geologijo, ekonomijo in politiko iz čistega veselja, ki ga imajo ob razumevanju teh področij.

Številni od teh »prostočasnih študijev ali konjičkov« imajo tudi družbeno pomembne razsežnosti. Človek, ki se nauči kovinarske obrti, mizarstva, opremljanja ali vrtnarjenja, kuhanja, šivanja ali izdelovanja cvetličnih aranžmajev, se je verjetno naučil tudi, kako prispevati h kakovosti družinskega življenja ali $\mathrm{k}$ blaginji. Na voljo so priložnosti za nepoklicno učenje in usposabljanje po mladostni dobi, ki imajo širši družbeni pomen.

\section{Izobraževanje za reševanje družbenih problemov}

Vse družbe v zgodovini človeštva so imele določene težave in koristilo bi jim, če bi njihovi člani te težave razumeli. Boljše razumevanje pa $\mathrm{v}$ preteklosti morda niti ne bi moglo veliko pomagati, saj so ljudje večinoma menili, da so tegobe človeštva posledica usode ali volje bogov in torej nerešljive. Odrešitev je bila mogoča le $v$ posmrtnem življenju (za kristjane in muslimane) ali $z$ umikom iz kolesja obstoja (za hindujce in budiste). V sodobnem svetu pa se je vendarle razvilo močno prepričanje, da lahko človek obvlada fizični svet in da lahko razume in usmerja lastno usodo. Morda je zaradi dogodkov v našem stoletju ta optimizem v zadnjih letih nekoliko uplahnil, vendar še zmeraj predstavlja prevladujoče načelo javne politike, ki trdi, da je usoda človeštva v njegovih rokah, če ne iz drugega razloga, pa zato, ker po mnenju mnogih druga možnost niti ne obstaja. V splošnem v naših družbah še vedno velja, da lahko znanje in morda uporaba znanja na koncu pomagata razrešiti vse težave.

\section{Ucenje osebnih in družbenih spretnosti}

Zaradi delovanja $v$ skladu $z$ zgoraj omenjeno domnevo je postal svet bolj zapleten ali pa morda zato dojemamo večji delež njegove kompleksnosti. Več ko vemo, bolj se zavedamo stvari, ki bi se jih morali še nauciti. Prav tako se zavedamo, da noben posameznik ne more obvladati vsega znanja. Vseeno pa zaradi dostopnosti vsakovrstnega znanja ljudje bolj verjamejo, da nekje obstaja določeno znanje, ki jim bo pomagalo razrešiti njihove težave. Sami lahko obvladajo in uporabijo tiste dele znanja, $\mathrm{ki}$ jih $\mathrm{v}$ določenem kontekstu potrebujejo, če pa tega ne morejo, se lahko zanesejo na to, da jim je na voljo strokovnjak, ki jim bo znal pomagati. Danes ne moremo več računati na izrabo znanja v okviru družine in bližnjega sosedstva. Člani ene družine zdaj pogosto živijo precej oddaljeni eden od drugega in $z$ njimi ni lahko priti v stik, izkušnje starejših rodov so pogosto tudi zastarele, obseg potrebnega razumevanja in znanj pa je prevelik, da bi lahko bil zajet $v$ tako majhni skupini ljudi. To pa vseeno ne povzroča težav, saj je dostopnost znanja zunaj lastnega malega kroga vse večja in lažja. Tako se torej obračamo na strokovnjake, ki naj opravijo stvari namesto nas ali pa naj nas naučijo tistega, kar vedo, in nam pokažejo, kako se to znanje uporablja. Precejšen del sistematičnega učenja po otroški dobi je te vrste. Ljudje verjamejo, da je velik del znanj in spretnosti (na primer o vzgoji otrok, o življenju v pokoju, o šofiranju avtomobila) moč spraviti v neko povezano in razumljivo obliko, ki se jo da pouče. vati in naučiti in, kar je najpomembnejše, koristno uporabiti. 


\section{Izobraževanje zal socialne vloge}

V preteklosti so se ljudje pripravljali na tradicionalne vloge v družbi in družini. Učili so jih (če sploh) sorodniki in prijatelji ali pa so ljudje sami opazovali vedenje oseb, ki so že prevzele svoje vloge in nastopale $v$ njih. Danes vse bolj menimo, da je tako učenje neustrezno ali nezanesljivo. $V$ razvitih državah se uveljavljajo delavnice in tečaji o življenju v družini, to temo pa vključujejo tudi $v$ izobraževalne programe $v$ deželah tretjega sveta (Brillinger in Brundage, 1985). V tečaje za matere in očete, ki jih v Veliki Britaniji organizira državna zveza za rojstvo otrok, se vključuje velik del bodočih staršev. V mnogih družbah obstaja izobraževalna ponudba tudi za druge družbene nepoklicne vloge. Za sprejem na določene politične položaje se ponekod že zahteva, da kandidat opravi določeno usposabljanje. Tudi zaposleni imajo marsikje zakonsko pravico do plačanega dopusta, da se usposobijo za delo v sindikatih (Hopkins, 1985).

\section{Pritiski družbe na posameznilka}

Poseganje družbe $v$ tako imenovane zasebne zadeve posameznika je danes tako močno, da bi ga lahko primerjali le $z$ nekdanjim vsiljevanjem ravnanja $v$ skladu $z$ verskimi dogma$m$ in pravili. $V$ družbah s socialnim varstvom je eden od razlogov za to paternalizem, češ, družba skuša kar najbolje poskrbeti za ljudi, pa naj jim je to všeč ali ne, vendar se poglavitni vzrok skriva v tem, da skoraj vsak del človekovega življenja vsaj potencialno vpliva na življenje drugih in se zanj zato družba lahko zanima. Družba torej iz lastnega interesa ne ravno sili, vsekakor pa spodbuja ljudi, naj se naučijo vesti v najrazličnejših situacijah. Opraviti moramo vozniški tečaj in izpit, preden smemo voziti avtomobil ali pilotirati letalo, saj bi v rokah neizurjenega človeka ta vozila lahko zakrivila nesreče. Družba nas spodbuja, da se naučimo, kako najbolje vzgajati otroke, ne le v njihovo korist, temveč tudi zato, ker bi slabo vzgojeni otroci lahko postali družbeno ali ekonomsko neprilagojeni in bi bili družbi v breme. Vedno večji problem so tudi starejši ljudje, ker jih je vedno več. S poučevanjem starejših je mogoče to težavo zmanjšati. Izobraževanje, ki je namenjeno določenim kategorijam ljudi ali ljudem v določenem položaju, pa ni omejeno le na razviti svet. Države v razvoju se zelo trudijo, da bi ljudi poučevali na zdravstvenem področju, zlasti o pravilni prehrani, higieni in o pomembnosti čiste pitne vode. Ne le v Evropi in Ameriki, temveč tudi v Afriki, Latinski Ameriki in drugod $v$ tretjem svetu namenjajo družbe večjo pozornost izobraževanju žensk, saj to prispeva k zmanjšanju ukoreninjene neenakosti med spoloma. Ražsirjena sta državljanska in politična vzgoja in to na vseh stopnjah razvoja družb. Državljanska vzgoja navadno zajema razvijanje odgovornega, obveščenega družbenega in političnega vedenja, ki naj podpira vlado. Tako vzgajanje je običajno v državah, kot je Kitajska (Hunter in Keehn, 1985). Načeloma velja, da so bili take vzgoje deležni vsi državljani socialističnih držav (Onushkin in Tonkonogaya, 1984), četudi v vzhodni Evropi ni več tako. V državah liberalne demokracije, kolikor ta obstaja, je namen državljanske vzgoje precej podoben, le da je $v$ njej manj odkrite indoktrinacije. Politična vzgoja ima lahko podobne cilje kot državljanska in ponekod gre za isto stvar z drugim imenom, vendar pa $v$ nekaterih deželah nanjo gledajo $z$ nezaupanjem, saj se lahko namerno ali nenamerno sprevrže v orodje, ki naj zruši vladajoči režim. Primer za to je delo Paola Freira.

\section{Izobraževanje \\ zoi premagovanje družbenih težtuv in socialne patologije}

Vprašanje ženskih pravic je eno tistih, za katera se zdi, da so se jih družbe zavedele šele pred kratkim, čeprav je vedno obstajalo. Tehnološke in družbene spremembe so sicer pomagale reševati obstoječe probleme, vendar so hkrati ustvarjale nove. Nekateri ogrožajo celo človeštvo, kot na primer učinek tople grede in druge ekološke nevarnosti, hitra rast svetovnega prebivalstva, povečevanje razlike med bogatimi in revnimi ter razlike v življenjski dobi med razvitimi državami in tretjim svetom, aids in narkomanija. Drugi problemi so bolj omejeni; takšna je na primer potreba po občutku nacionalne identitete v nekaterih nekdanjih kolonijah, težave, ki jih ustvarja velika imigracija, in druge. $V$ preteklosti so bila sredstva in pravice do ukrepanja pri reševanju tako velikih in globalnih problemov omejena na majhen krog ljudi. Od množic ni nihče pričakoval, da naj bi razumele žgoča vprašanja, temveč naj bi preprosto ubogale. Danes pa tudi v najbolj diktatorskih režimih vodjem ustreza, če so državljani prepričani, da sami nosijo velik del odgovornosti za oblikovanje javne politike. Ce ljudje razumejo in odobravajo javno politiko, jo je tudi lažje izvajati. Seveda pa so še druge vrste politik, v katerih obstaja resnična odgovornost.

$\checkmark$ nekaterih položajih lahko $\mathrm{k}$ uspešnosti ukrepov pripomore le delovanje množic, ki pa mora temeljiti na razumevanju. V številnih državah izvajajo množične izobraževalne kampanje v šolah in po mladostnem obdobju, da bi zmanjšali stopnjo rojstev (UNESCO, 1978). Izobraževanje se uporablja tudi v boju proti narkomaniji in aidsu. Okoliščine za množično izobraževanje so vse ugodnejše, saj se zaradi hitrejše komunikacije v današnjem svetu vse bolj zavedamo odvisnosti in povezanosti vseh ljudi na planetu. Na voljo so komunikacijska tehnologija in metode za razširjanje informacij, ki lahko dosežejo ljudi po vsem svetu. Vendar pa je značilnost modernega sveta, da se je s povečanjem možnosti za razširjanje znanja povečala tudi možnost za manipulacijo in izkrivljanje podatkov.

\section{Religiozni element}

Cetudi izobraževanje pripomore $\mathrm{k}$ zmanjšanju težav na tem svetu, pa vsi ljudje svojega življenja v fizičnem univerzumu ne jemljejo kot celoto in namen človekove usode. Nekateri trdijo, da obstajajo razsežnosti zunaj empirične razsežnosti čutov, da obstaja red in da je navidezni kaos življenja le del tega reda. Menijo, da mora obstajati neko prvotno počelo, neka uteha po smrti, ki naj poplača posameznika za njegovo trpljenje v življenju. Izobraževanje, ki ga navdihuje religioznost, je še vedno zanimivo za ljudi vseh starosti. To velja bolj za tretji svet kot za razvite dežele, vseeno pa vidimo, da so krščanske cerkve glavni ponudniki splošnega in specializiranega religioznega izobraževanja v ZRN, na Nizozemskem in v Skandinaviji.V državah v razvoju opravljajo to vlogo $v$ okviru svojih misijonarskih nalog. V Latinski Ameriki so napadali religiozno izobraževalno delovanje protestantske cerkve, češ da gre za ameriški poskus kolonizacije duha, in tako tam učijo katoliški duhovniki revolucionarno teologijo iz političnih, in ne le iz duhovnih razlogov (Retamal, 1982). Tudi druga verstva so podobno dejavna. V Aziji se na primer pri budizmu močno navdihujeta gibanje Sarvodaya Shramamdana na Šri Lanki (Ariyaratne, 1985), ki je v svoje roke prevzelo celovit razvoj 
podeželja, ter Khit-Pen, tajska filozofija in program izobraževanja za odrasle (Titmus, 1989).

\section{Izobrăevanie, ki je le postransko povezuno z zcemim izobraževanjem}

Lahko bi trdili, da je vsako izobraževanje, ki ga ne razumemo kot kompenzacijo za neprejeto začetno izobraževanje in ne kot končno stopnjo začetnega izobraževanja, dopolnilno. To pa je res le, če dopolnilno izobraževanje razumemo kot zelo širok pojem. Del učenja po otroški dobi je progresivnega (zaporednega) ali hierarhičnega značaja, saj gradi neposredno na prejšnjem znanju in novo učenje tudi ne bi bilo mogoče brez njega. Takšna je večina ekspertnega izobraževanja na znanstvenem in tehnološkem področju in če je na voljo odraslim, se domneva, da so dosegli določeno stopnjo v rednem začetnem izobraževanju v šolah. Če odrasle poučujemo predmete, ki so sicer del šolskega programa, pogosto domnevamo, da imajo znanje, ki ga bo izobraževanje v odrasli dobi dopolnjevalo, tudi pri zgodovini, jezikih, književnosti in družbenih vedah, pri katerih napredovanje ni preprosto linearno. Izobraževanje po otroški dobi večkrat zajema akademske stroke, ki sicer niso del šolskega programa, na primer arheologijo, filozofijo, politiko ali druge jezike, kot sta tista dva ali trije, ki jih navadno učijo v soli; lahko pa tako izobraževanje sploh nima zveze $z$ akademskimi strokami, temveč se ukvarja $z$ vrstami vedenj in žgočimi vprašanji, kot so vprašanja splava, jedrske energije ali pravic žensk. Take učne izkušnje lahko imamo za dopolnilne le v smislu, da temeljijo na domnevi, da učeči se odrasli obvladajo skupek splošnega znanja in izkušenj, ki so si jih lahko pridobili v šoli, v družini in iz drugih virov zunaj formalnega izobraževanja.

Nujno znanje, ki mu je učenje po otroški dobi dopolnilno, je pogosto omejeno na osnovno pismenost in znanje računstva. Ti dve osnovni spretnosti sta lahko $v$ mnogih okolišcinah zaželeni, vendar ne nujni pogoj za učenje. Matere v deželah tretjega sveta se lahko učijo zdravstvenega varstva, razvijejo razumevanje o pripadnosti narodu, si pridobe umetniške ali obrtniške sposobnosti in spretnosti, izboljšajo način obdelovanja zemlje brez znanja branja, pisanja in računstva. Vidimo torej, da je povezava med kasnejšim učnjem in izobraževanjem v otroštvu lahko zelo rahla in nebistvena. Kjer pa je za učenje v odrasli dobi treba imeti določene izkušnje, so si jih ljudje pogosto pridobili naključno ali mimogrede, in ne s prejšnjim namenskim učenjem. Celo izkušnje iz otroške dobe so lahko brezpredmetne za udeležence tečaja za bodoče starše, za ljudi, ki se pripravljajo na upokojitev, ali za osebe, ki se učijo o družbeni nevarnosti aidsa in narkomanije. S tem nočemo reči, da se otroci ne morejo s koristjo učiti o številnih vprašanjih, ki se jih po navadi obravnava šele v dobi po otroštvu, celo zaželeno je, da se tega učijo. Gre za to, da večina odraslih $\mathrm{v}$ otroštvu ni doživela nič takega, kar bi jim kot odraslim pomagalo k razumevanju obravnavanih vprašanj. Nekateri učitelji celo zastopajo mnenje, da bi bilo skoraj dobro izpustiti določena znanja iz izobraževanja za otroke ali vsaj raje učiti pozneje. Nekdo je rekel: »Prepričan sem, da je za ta študij (šlo je za področja humanističnih in družbenih ved) primernejše obdobje po osemnajstem letu, še boljša pa doba po tridesetem letu.« (Livingstone, 1941)

\section{Sklep}

Na prejšnjih straneh sem poskušal predstaviti vso raznovrstnost izobraževalne ponudbe za odrasle. Ta je tako velika, da se včasih zdi, da so na voljo možnosti in priložnosti, ki lahko ustrežejo vsaki zahtevi po znanju, ki si jo le lahko zamislimo. In ne le to, očitno obstajajo tudi prepričljivi razlogi za začetek takega študija. Kljub temu pa se tudi v državah, kjer imajo najvišjo stopnjo udeležbe, na primer na Švedskem in $v$ ZDA, le manjšina odraslih vključuje v programe namenskega učenja. Veliko ljudi se nikoli ne odloči, da bodo sodelovali v izobraževalnem programu za odrasle.

Colin, dr. Titmus

Profesor na univerzi v Leedsu 